IMEJ: Islamic Management and Empowerment Journal

Volume 2, Number 2, Juni 2020. p. 203-224

P-ISSN:2685-953X; e-ISSN:2686-0317

DOI: 10.18326/imej.v2i2.203-224

website: http://e-journal.iainsalatiga.ac.id/index.php/imej

\title{
Pemberdayaan Berbasis Religi: Melihat Fungsi Masjid Sebagai Ruang Religi, Edukasi dan Kultural di Masjid Darusa'adah, Kota Bandung
}

\author{
Nurlaili Khikmawati \\ IAIN Syekh Nurjati Cirebon \\ lailinur.kh0306@gmail.com
}

\begin{abstract}
Mosques generally have a primary function as a place of worship. This paper aims to explain and analyze the function and role of the Darussa'adah Mosque in religious, educational and cultural spaces. In this case it is closely related to community empowerment. The data obtained comes from field research. Apart from that, participatory observations were also carried out, in which researchers directly participated in all activities in the mosque. The results showed first, the Darusa'adah Mosque in Dago Village has a main function as a place of worship and preaching through lectures. Second, the Darussa'adah Mosque also has a role in developing religious education through MDTA and PAUD. Third, the solidarity of the community around the Darussa'adah Mosque is getting stronger with the support of majelis taklim activities in the mosque.
\end{abstract}

Keywords: Mosque; Empowerment; Religion; Education

\begin{abstract}
Abstrak
Masjid pada umumnya memiliki fungsi utama sebagai tempat ibadah. Tulisan ini bertujuan untuk menjelaskan dan menganalisa fungsi dan peran Masjid Darussa'adah dalam ruang religi, edukasi dan kultural. Dalam hal ini sangat berkaitan dengan pemberdayaan masyarakat. Data yang didapatkan berasal dari penelitian lapangan. Selain itu, juga dilakukan observasi partisipatoris yaitu peneliti langsung terjun mengikuti semua kegiatan yang ada di masjid. Hasil penelitian menunjukkan pertama, Masjid Darusa'adah yang ada di Kelurahan Dago, memiliki fungsi utama sebagai tempat ibadah dan berdakwah lewat ceramah. Kedua, memiliki peran dalam mengembangkan pendidikan agama melalui MDTA dan PAUD. Ketiga, solidaritas masyarakat sekitar Masjid Darussa'adah semakin kuat dengan didukung kegiatan majelis taklim yang ada di masjid.
\end{abstract}

Kata Kunci: Kata Kunci: Masjid; Pemberdayaan; Religi; Pendidikan 


\section{Pendahuluan}

Kebudayaan memiliki tujuh unsur universal yaitu bahasa, kesenian, mata pencaharian, sistem pengetahuan, sistem kepercayaan, organisasi sosial dan teknologi. Salah satu diantarannya dapat dilihat dari sistem kepercayaan. Menurut Talott Pasrsons sistem kepercayaan masyarakat diwujudkan dalam berbagai ritual keagamaan yang dilakukan pada tempat-tempat tertentu yang dianggap sakral dan suci. Sistem kepercayaan banyak dianut oleh masyarakat dalam sistem agama. Agama memiliki posisi yang penting dalam sistem kehidupan masyarakat karena agama memberikan kepastian dan mengatur stabilitas sosial (Furseth \& Repstad, 2006). Dalam sistem agama terdapat nilai dan norma yang digunakan dalam masyarakat untuk menjaga keteraturan sosial. Selain itu, masyarakat juga menjadikan sistem agama sebagai pedoman dalam berperilaku.

Agama dalam hal ini memlili dua sisi yaitu sakral dan profan. Dalam menjalankan aktivitas keagamaan, masyarakat melakukan ritual yang sifatnya lebih sakral. Sesuatu yang sakral bisa dilihat dari pakaian, aktivitas dan tempat saat melakukan ritual. Sebaliknya, selain melakukan hal yang sakral, dalam aktivitas beragama masyarakat juga melakukan aktivitas yang profan. Artinya tindakan dan perilaku di luar hal sakral, tindakan beragama tersebut termasuk dalam hal profan.

Dalam konteks Indonesia, terdapat enam agama dan kepercayaan yang diakui pemerintah. Salah satu yang diakui tersebut adalah Islam. Islam menjadi agama mayoritas di Indonesia dan pemeluknya tersebar di seluruh wilayah Indonesia. Bahkan data dari global religious futures jumlah penduduk muslim di Indonesia pada tahun 2020 mencapai 229,62 juta jiwa. Angka tersebut menunjukkan bahwa Indonesia sebagai negara dengan jumlah muslim terbesar di dunia (Katadata.co.id, 2018). Peringkat kedua setelah Indonesia adalah India.

Dalam melaksanakan ibadah, masyakat penganut Islam (muslim) memiliki tempat sentral yang disebut masjid atau mushola. Dengan muslim sebagai mayoritas, keberadaan masjid juga tersebar di seluruh wilayah Indonesia. Berdasarkan data dari Sistem Informasi Masjid Kementerian Agama, pada tahun 2020 jumlah masjid di Indonesia sebanyak 274.241 (Kemenag, 2020). 
Dalam pengertian sehari-hari masjid disebut sebagai bangunan tempat melakukan segala aktivitas yang mengadung kepatuhan kepada Allah SWT (Ayubi, 2008). Hal ini sejalan dengan firman Allah pada surat Jin yang berarti "Dan sesungguhnya masjid-masjid itu adalah untuk Allah. Maka janganlah kamu menyembah apapun di dalamnya selain Allah" (Endang, Gufron, Zaenudin, \& Rahman, 2012). Fungsi masjid sebagai tempat ibadah semacam inilah yang nampaknya banyak berlaku di sebagian besar masyarakat Indonesia. Masjid akan berpenghuni saat-saat waktu ibadah tertentu seperti waktu sholat lima waktu, sholat jumat, dan sholat hari raya. Di beberapa wilayah, masjid sepi pengunjung dengan berbagai alasan yang dimiliki masyarakatnya.

Berdasarkan kategorisasi tempat umum oleh Carmona, masjid merupakan the third-place spaces dengan ciri sebagai tempat sosial dan pertemuan yang semi-umum. Artinya, masjid tidak dimiliki oleh nama pribadi namun tidak semua orang bisa menggunakan masjid sebagai tempat beribadah (Johnston, 2013). Hal ini menunjukkan masjid adalah social space untuk kepentingan tertentu.

Bagi masyarakat Indonesia, masjid tidak sekedar bangunan yang mengandung nilai religius. Sebagai wilayah yang memiliki beragam budaya, bangunan-bangunan masjid juga memiliki ciri khas sebagaimana kondisi sosial budaya masyarakat. Hal ini berkaitan dengan sejarah persebaran Islam di Indonesia yang banyak menghasilkan produk-produk akulturasi. Misalnya, masjid laksamana cheng ho yang dibangun dengan arsitektur cina. Fleksibelitas bangunan masjid dan uniknya arsitektur masjid membawa nilai estetika yang dapat dijadikan sebagai tempat rekreasi.

Dalam melihat bentuk dan fungsi masjid, terdapat satu masjid yang cukup menarik untuk dibahas dan dianalisa. Masjid Darusa'adah yang berada di Kota Bandung. Lokasi tepatnya berada di Kelurahan Dago, Kecamatan Coblong, Kota Bandung. Masjid ini tidak hanya sebagai tempat ibadah saja, namun masjid ini juga berfungsi sebagai ruang pendidikan, sosial dan budaya. Letaknya yang dekat dengan pusat kota, menjadikan masjid ini memiliki peran sentral dalam mengembangkan nilai agama dan pendidikan. Selain itu, Masjid Darusa'adah juga berperan menjadi ruang pertemuan ide dan gagasan 
masyarakat.

Seluruh masjid memiliki fungsi utama sebagai tempat ibadah. Namun, sekarang fungsi masjid mengalami perkembangan. Beberapa masjid misal dapat berfungsi sebagai tempat digelarnya hajatan, hiburan religi atau wisata religi. Begitu juga Masjid Darusa'adah yang mengalami perkembangan dan lebih memilih fungsi edukasi dan kultural. Melihat perkembangan itu, akhirnya fungsi religi, edukasi dan kultural akan menjadi suatu analisa dengan konsep pemberdayaan masyarakat. Pemberdayaan tersebut dilakukan dalam lingkup religi yaitu peran masjid sebagai ruang religi, edukasi dan kultural.

\section{Masjid Sebagai Ruang Religi, Edukasi dan Kultural}

Masjid sejatinya sebagi tempat ibadah umat Islam. Masyarakat lebih banyak mengetahui bahwa masjid hanya untuk ibadah. Bahkan bagi sebagian masyarakat menganggap jika ada kegiatan lain selain ibadah di masjid, adalah sesuatu yang tabu. Namun sebenarnya, sejak zaman Rasulullah S.A.W, masjid juga menjadi ruang untuk pendidikan, perkumpulan, bahkan sampai pada ruang politik Islam.

Awal perkembangan masjid dalam umat Islam dapat dilihat pada zaman Rasulullah di mana masjid memiliki peran yang sangat penting dalam kehidupan masyarakat. Masjid menjadi basis ilmu, sosial, dan politik pada masa Rasulullah bahkan sampai pada masamasa setelah Rasulullah. Dimulai dari masjid, Rasulullah membangun kader-kader terbaik umat Islam untuk memimpin, mewarisi, dan memelihara ajaran Islam. Pada masa setelah Rasululullah, masjid mampu menjadi pusat kebudayaan Islam dan pusat berkembangnya ilmu pengetahuan baik agama maupun umum (Putra \& Rumondor, 2019). Fungsi masjid dalam kerangka pemberdayaan religi ini, dapat dilihat dalam beberapa konsep. Pertama, konsep keberadaan masjid sebagai ruang ibadah dan dakwah, kedua konsep pemberdayaan yang berbasis religi, ketiga fungsi masjid dalam konteks edukasi dan sosio kultural.

Pertama, masjid dilihat sebagai ruang ibadah dan dakwah. Peran dan fungsi masjid terhadap peradaban Islam adalah sebagai tempat ibadah, kedua sebagai tempat sosial, ketiga sebagai tempat 
dakwah Islam dan keempat sebagai pemberdayaan ekonomi umat, dan kelima sebagai pusat kaderisasi umat, dan keenam sebagai tempat sarana kesehatan (Karim, 2020). Dalam pengertian ini fungsi dan peran masjid yang pertama adalah sebagai tempat ibadah, lalu juga sebagai tempat dakwah Islam.

Ketika dilihat dalam historisnya, masjid sebagai ruang dakwah Islam, telah dimulai sejak zaman Rasulullah yaitu di Masjid Nabawi Madinah. Konteksnya pada waktu itu dengan caara menumbuhkan dan membangun potensi spiritual masyarakat, membangun pranata sosial. Salah satu pranata yang dibangun waktu itu adalah membangun masjid, membuat perjanjian damai, membangun pasar, memberikan pelatihan apsukan pertahanan dan kebersamaan umat (Nurjamilah, 2017). Sampai di sini dapat dipahami bahwa masjid secara histori bukan hanya sekedar tempat ibadah. Keberadaannya juga berkaitan dengan peran lain.

Kedua, masjid berkaitan dengan pemberdayaan masyarakat. Pemberdayaan ini berbasis religi/agama. Hasil studi tentang hal tersebut menunjukkan bahwa masjid dapat menhhidupkan semangat pemberdayaan masyarkat dalam bidang spiritual, ekonomi, pendidikan, sosial, dan seni. Hal ini didukung dengan sumber daya manusia yang memadai. Profesionalisme pengelolaan masjid dan komunikasi menjadi hal penting dalam pemberayaan berbasis masjid (Ridwanullah \& Herdiana, 2018). Masjid dalam hal ini telah mampu menunjukkan perannya dalam melakukan pemberdayaan

Pemberdayaan dengan konteks religi juga dapat dilakukan dengan kegiatan mahasiswa. Dalam kegiatan KKN mahasiswa misalkan dapat menjalankan program pendidikan seperti SERULAGA (serunya belajat agama). Selain itu kegiatan pemberdayaan juga bisa dilakuakan dalam bidang pendidikan, sosial, dan ekonomi (Amir \& Nasution, 2018). Konsep pemberdayaan berbasis religi lebih mengutamakan kegiatan atau aktivitas yang dapat meningkatkan kegiatan keagamaan. Dalam hal ini, masyarakat melakukan pengoranisasian sehingga dalam perilaku beragama tidak hanya dimaknai sebagai hubungan manusia dengan Tuhan.

Ketiga, masjid dapat juga dilihat dalam konteks edukasi dan sosio kultural. Beberapa studi telah membahasnya. Masjid bagi orang 
dewasa digunakan sebagai tempat belajar al Quran, hadis dan dasardasar agama, serta belajar keterampilan menenun atau memintal. Sedangkan bagi anak-anak, mereka belajar di serambi masjid dengan materi agama sampai keterampilan berkuda. Hal itu dilakukan sejak zaman Rasulullah. Namun, sekarang tidak semua masjid melakukan hal yang sama. Hal ini lah yang perlu direkonstruksi untuk kembali memfungsikan masjid seperti zaman dahulu (Darodjat \& Wahyudiana, 2014).

Hasil studi lain tentang masjid sebagai ruang sosial dan kultural menjelaskan bahwa masyarakat dapat memulai pengorganisasian lewat masjid. Sebelum kampung wisata Saiydan Yogyakarta dibentuk, awalnya masyarakat resah dengan kondisi sungai yang kadang mendatangkan banjir. Kemudian, community organizing diawali dari base camp di masjid yang meghasilkan ide membuat kampung wisata. Kemudian, dibuatlah kampung wisata berbasis masjid dengan rangkaian kegiatannya yaitu discovery, dream, desgin, define dan destiny (Kharis, 2019). Dapat dilihat bahwa ternyata masjid dapat menjadi ruang dalam pembentukan ide untuk menyelesaikan masalah.

Masjid secara histori dan perkembangannya banyak mengalami dinamika. Perkembangan tersebut tidak akan sama dari segi waktu dan tempat. Fungsi dan peran masjid sebagai tempat ibadah umat Islam, telah mengalami pergerseran atau pemaknaan ulang. Bahkan hal tersebut, seolah ingin mengembalikan fungsi masjid seperti zaman Rasululah yaitu masjid juga punya peran dalam bidang pendidikan, sosial dan budaya.

\section{Metode Penelitian}

Penelitian ini merupakan jenis penelitian lapangan (field research) dan dideskripsikan dengan metode kualitatif. Pemilihan metode kualitaf memungkinkan data terdeskripsikan secara rinci karena data data penelitian tidak dapat disatistikkan. Penelitian ini dilakukan di Masjid Darussa'adah di Kelurahan Dago, Kecamtan Coblong, Kota Bandung. Lokasi masjid Darussaadah berada di tengah gang sempit di permukiman padat penduduk. Masjid ini berusia cukup tua namun bangunan masjid masih kokoh sehingga keberadaannya selalu ramai oleh aktivotas masyarakat. 
Data-data dalam penelitian ini diperoleh dengan cara observasi partisipatoris di mana peneliti terlibat langsung dalam setiap kegiatan yang di adakan masjid. Data-data penelitian juga diperoleh dengan cara wawancara mendalam dan dokumentasi. Data-data peneltoan kemudian diolah dengan dukungan kepustakan yang relevan dengan hasil penelitian. Dalam proses penelitian, tidak semua data diterima begitu saja namun peneliti melakukan konfirmasi data misalnya data hasil wawancara dikonfirmasi dengan data hasil pengamatan, dan sebaliknya. Dalam proses pengolahan data, tidak semua data yang masuk ditulis oleh peneliti namun peneliti melakukan reduksi data dan memilih data yang sesuai dengan kajian penelitian. Kemudian pada tahapan terakhir, peneliti mengambil kesimpulan dari semua data yang didapatkan.

\section{Hasil dan Pembahasan}

\section{Masjid Darusa'adah: Kondisi Fisik dan Lingkungan}

Kelurahan Dago merupakan salah satu wilayah yang ramai di Kota Bandung. Letaknya yang berada di area Jl. Juanda menjadi wilayah yang startegis dan banyak dilewati bahkan dikunjungi oleh banyak orang, baik sekedar untuk singgah maupun menetap dalam jangka waktu lama untuk urusan pendidikan ataupun pekerjaan. Sebelum lebih jauh, terlebih dahulu dilihat kondisi masyarakat Kelurahan Dago. Berikut data penduduk Kelurahan Dago, Kecamatan Coblong, Kota Bandung tahun 2019.

Tabel 1. Penduduk Kelurahan Dago Kecamatan Coblong menurut Kelompok Umur tahun 2019

\begin{tabular}{crrr}
\hline Kelompok Umur & Pria & Wanita & Jumlah \\
\hline Age Group & Male & Female & Total \\
$\mathbf{0 - 4}$ & 1300 & 1178 & 2478 \\
$\mathbf{5 - 9}$ & 1501 & 1391 & 2892 \\
$\mathbf{1 0 - 1 4}$ & 1452 & 1343 & 2795 \\
$\mathbf{1 5 - 1 9}$ & 1262 & 1250 & 2512 \\
$\mathbf{2 0 - 2 4}$ & 1412 & 1236 & 2648 \\
$\mathbf{2 5 - 2 9}$ & 1347 & 1355 & 2702 \\
$\mathbf{3 0 - 3 4}$ & 1290 & 1259 & 2549 \\
$\mathbf{3 5 - 3 9}$ & 1557 & 1432 & 2989 \\
$\mathbf{4 0 - 4 4}$ & 1286 & 1281 & 2567 \\
\hline
\end{tabular}




\begin{tabular}{crrr}
\hline Kelompok Umur & Pria & Wanita & Jumlah \\
\hline $\mathbf{4 5 - 4 9}$ & 1167 & 1223 & 2390 \\
$\mathbf{5 0 - 5 4}$ & 1059 & 1041 & 2100 \\
$\mathbf{5 5 - 5 9}$ & 826 & 884 & 1710 \\
$\mathbf{6 0 - 6 4}$ & 680 & 738 & 1418 \\
$\mathbf{6 5 - 6 9}$ & 518 & 507 & 1025 \\
$\mathbf{7 0 - 7 4}$ & 246 & 325 & 571 \\
$\mathbf{7 5 +}$ & 458 & 491 & 949 \\
\hline Jumlah & 17361 & 16934 & 34295 \\
\hline
\end{tabular}

Sumber: BPS Kota Bandung, 2020

Tabel 1 menunjukkan bahwa jumlah penduduk Keluarahan Dago Kecamatan Coblong Kota Bandung adalah 34.295 jiwa. Dari jumlah tersebut laki-laki memiliki jumlah lebih besar yaotu 17.361 jiwa. Sedangkan jika dilihat dari kelompok usia, jumlah terbesar adalah kelompok usia 35-39 tahun dengan jumlah 2.989 jiwa (BPS, 2020). Dengan jumlah tersebut, Kelurahan Dago termasuk kawasan dengan jumlah penduduk tinggi untuk ukuran satu kelurahan.

Dengan jumlah penduduk yang cukup tinggi berdampak pada banyak pendirian bangunan-bangunan perkantoran maupun perumahan yang dimiliki oleh penduduk pendatang dan lahan milik penduduk asli semakin berkurang. Salah satunya dapat dilihat dari jumlah hotel di Kelurahan Dago. BPS Kota Bandung (2016) mencatat bahwa terdapat 17 hotel yang ada di Keluragan Dago.Di sisi lain, sebagian besar penduduk asli tinggal dipermukikan yang padat penduduk sebagaimana di Cihaur.

Cihaur merupakan salah satu blok yang terletak di Kelurahan Dago. Lokasinya masuk dari Jl. Juanda. Saat masuk ke wilayah Cihaur, jalannya lebar dan beraspal, dipinggirnya terdapat rumah-rumah besar bahkan ada bangunan Politeknik Manufaktur atau disebut Polman. Namun saat menyusuri Cihaur lebih ke dalam, akan nampak perumahan padat penduduk yang jalannya hanya dapat dilalui oleh kendaraan roda dua. Bangunan-bangunannya terdiri dari rumahrumah padat dan kecil yang sebagian dimanfaatkan juga untuk warung. Di tengah perumahan ini terdapat masjid berlantai 2 yang diberi nama Masjid Darussa'adah. 
Masjid Darussa'adah berada di RT 02 RW 08 Jl. Kanayakan Cihaur, Kelurahan Dago Kecamatan Coblong, Kota Bandung, Jawa Barat. Masjid ini berlokasi di tengah-tengah pemukiman padat penduduk dengan jalan kecil yang hanya dapat dilewati oleh kendaraan roda dua. Berikut gambaran lokasi masjid dalam denah.

Gambar 1. Denah Lokasi Masjid Darusa'adah
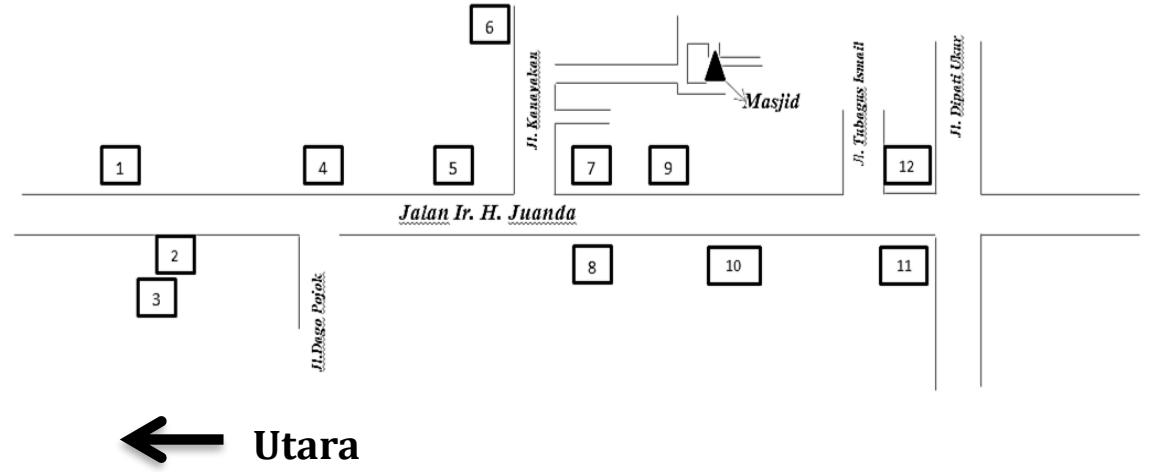

Usia Masjid Darusa'adah sudah lebih dari 60 tahun. Masjid Daarusa'adah dibangun pada tahun 1960an oleh Ajengan Kamaludin. Pada saat pendirian, masjid ini berada di atas tanah pribadi milik Ajengan Kamaludin dengan luas 7 x $5 \mathrm{~m}$. Sejak awal pendiriannya, Masjid Daarusaaah mengalami satu kali renovasi pada tahun 1980. Renovasi ini menambahkan menara dan menambah luas wilayah masjid. Dengan bertambahnya fasilitas ini, menjadikan masjid lebih nyaman sebagai tempat untuk melakukan ibadah.

Setelah mengalami renovasi, masjid Daarusa'adah memiliki luas $205 \mathrm{~m}^{2}$ dan memiliki dua lantai bangunan. Dalam pemanfaatannya, bangunan masjid dibagi menjadi wilayah berdasarka jenis kelamin. Lantai satu atau bangunan utama masjid digunakan untuk jamaah laki-laki dan perempuan dengan pembagian laki-laki di depan dan perempuan di belakang. Pembagian wilayah berdasarkan jenis kelamin ini cukup banyak terdapat di masjid-masjid dengan batas hijab berupa kain putih. Lantai dua masjid dikhususkan sebagai ruang cadangan saat lantai satu penuh telah penuh terisi jamaah. Biasanya ini dilakukan saat Sholat Jum'at atau Sholat Hari Raya. 
Terdapat beberapa fasilitas yang ada di Masjid Daarusa'adah yaitu mukena, kamar mandi dan tempat wudhu, kantor takmir, meja, kursi, papan tulis, ruang ustadz dan beberapa alat bermain anak-anak. Masjid Darusa'adah dilengkapi dengan ruang kelas yang difungsikan sebagai tempat Pendidikan Anak Usia Dini (PAUD). Seluruh fasilitas masjid ini dikelola oleh ketua RW, Dewan Kemakmuran Majid (DKM), serta ustadz dan ustadzahnya. Semua stakeholders tersebut berperan dalam menerapkan manajemen masjid.

Dengan kondisi fisik dan fasilitas Masjid Nurusa'adah yang demikian, membuat suasan masjid nyaman untuk digunakan segala aktivitas masyarakat termasuk ibadah. Menurut ketua reemaja masjid yang menjabat pada tahun 2006, Masjid Darusa'adah memiliki suasana yang tenang dan kondusif untuk beribadah. Lokasi masjid yang jauh dari jalan raya membuat situasi masjid leih sepi, tidak berisik dan mendukung untuk jamaah melakukan ibadah. Semakin sepi lokasi tempat ibadah, semakin tenang untuk dapat melakukan ibadah.

\section{Melihat Ulang Fungsi Masjid: Perspektif Religi}

Ditinjau dari sejarahnya, pada zaman Rasulullah masjid memiliki banyak fungsi. Alih-alih masjid menjadi tempat ibadah dan menjalin hubungan manusia dengan Tuhannya, masjid juga menjadi ruang sosial tempat manusia menyeleraskan hubungan sosial budaya dengan sesama manusia termasuk di dalamnya dalam menyusun strategi perang dan merawat korban perang.

Saat ini, kondisi sosial budaya masyarakat telah berbeda dengan kondisi sosial budaya masyarakat pada masa Rasulullah. Fungsi masjid juga dimungkinkan mengalami perbedaan. Ditambah saat ini banyak adanya program pembangunan pemerintah yang memfokuskan pada bidang infrastruktur sehingga bangunanbangunan banyak dikhususkan sesuai dengan fungsinya yang lebih spesifik. Secara lebih spesifik berikut beberapa fungsi dan peran Masjid Darusa'adah, Keluarhan Dago.

\section{Tempat Ibadah}

Dalam pembahasan ini, ibadah yang dimaskud adalah sholat wajib lima waktu secara berjamaah. Masjid Darusa'adah membuka 
masjid untuk sholat lima waktu, sholat jumat, sholat hari raya idul fitri dan hari raya idul adha, sholat tarawih dan witir serta sholat-sholat pada momen tertentu seperti sholat gerhana.

Pada kesehariannya, Masjid Daarusa'adah mengumandangnkan azan dan iqomah untuk menarik jamaah sholat lima waktu. Meskipun demikian, jumlah jamaah tidak selalu sama dalam setiap waktunya. Pada shalat subuh, maghrib, dan isya jumlah jamaah cenderung lebih banyak. Pada shalat subuh, sebagain besar penduduk sekitar masjid masih berada di rumah (belum pergi bekerja) sehingga dapat mengikuti sholat berjamaah, sedangkan pada waktu maghrib dan isya jamaah sholat ditambah oleh anak-anak yang juga mengaji di Madrasah Diniyah. Pada waktu dhuhur dan ashar, jumlah jamah berkurang dkarenakan sebagian penduduk masih pada di tempat kerja dan anak-anak masih berada di sekolah.

Secara umum, perbedaan jamaah ini tidak hanya dipengaruhi oleh aktivitas penduduk sekitar namun juga waktu seperti saat Bulan Ramadhan. Bulan Ramadhan merupakan bulan yang istimewa bagi masyarakat muslim. Keistimewaan itu diwujudkan dengan beberapa ritual ibadah khusus seperti sholat tarawih dan witir. Banyak penduduk yang pada bulan-bulan lain tidak berjamaah ke masjid namun pada Bulan Ramadhan banyak penduduk yang datang ke masjid untuk melakasanakan shalat isya berjamaah dilanjutkan sholat tarawih dan witir. Pada bulan ini, jamaah Sholat Tarawih meningkat tiga kali lipat.

"Kalau hari-hari biasa ya sekitar 20an orang neng, yang ikut campur, ada yang anak-naka kecil, remaja, dewasa, sama ibu-ibu. Tapi paling banyak laki-laki. Selama puasa jamaahnya meningkat sampai menjadi tiga kali lipat. Kalau hari biasa masjid berisi sepertiga saja, maka saat puasa majid bias berisi tiga per tiga" (Ketua RW, Kelurahan Dago)

Berdasarkan hasil pengamatan, dari awal sampai akhir Bulan Ramadhan jumlah jamaah mengalami penurunan. Pada awal datangnya Bulan Ramadhan, jumlah jamaah meluas sampai ke lantai dua namun semakin hari jumlah berkurang dilihat dari lantai satu yang sudah longgar oleh jamaah. Hal ini juga banyak terjadi di beberapa masjid lain. 
Sholat tarawih dilakukan setelah shalat isya dengan diselingi kultum atau ceramah. Penceramah bergantung pada imam (pemimpin sholat) karena penceramah sekaligus bertugas sebagai imam. Namun demikian, seperti sholat-sholat jamaah yang lain, imam tidak memiliki jadwal yang ketat sehingga ceramah juga tidak diberikan setiap hari.

Berlangsungnya shalat jamaah di Masjid Darussa'adah dipimpin oleh seorang imam laki-laki. Imam ini tidak di dasarkan pada jadwal yang ketat. Imam bersifat fleksibel bergantung pada siapa saja yang ada dan bisa. Begitu juga muadzin, muazin tidak harus selalu dilakukan oleh ustadz atau penjaga masjid. Azan boleh dilakukan oleh siapa saja yang ada di masjid. Bahkan azan juga dapat dilakukan oleh anak kecil santri madrasah diniyah.

\section{Tempat Dakwah}

Dakwah dalam hal ini dilakukan dengan ceramah. Penyampaian Ceramah salah satunya disampaikan pada Bulan Ramadhan di selasela sholat isya dan tarawih. Ceramah ini tidak disampaikan dengan Bahasa Sunda, melainkan dalam Bahasa Indonesia. Hal ini memudahkan jamaah yang berasal dari luar Sunda memahami isi ceramah. Sesekali saja ceramah diselingi dengan kalimat-kalimat berbahsa sunda. Ceramah dengan cara seperti ini disesuaikan dengan kondisi jamaah yang sebagian merupakan warga pendatang atau pemukim sementara.

Bahasa Indonesia yang digunakan saat ceramah juga disisipi dnegan bahasa-bahasa serapan baik dari bahasa Arab yang mencirikan Islam maupun bahasa serapan lainnya. Bahasa Arab yang dipakai misalnya mustajab yang berarti mudah terkabulkan. Sedangkan bahasa serapan lain adalah sistematika yang bebasal dari Bahasa Inggris dan berarti susunan. Penggunaan bahasa ini biasanya bahasa yang sudah akrab di telinga jamaah dan sering digunakan dalam percakapan sehari-hari.

Selama Bulan Ramadan, ceramah disampaikan dengan tema yang bermacam- macam, dari tema tentang agama dan ketuhanan sampai dengan tema tentang kehidupan bermasyarakat seperti tema tentang kebersihan kota. Mengemas ceramah dengan Bahasa Indonesia dan tema sosial yang lebih umum, membuat kegatan ceramah tidak monoton dan lebih mudah diterima oleh masyakat 
umum masyakarat perkotaan.

Pola aktivitas dakwah tersebut secara tidak langsung telah menggunakan manajemen dakwah. Artinya ada pengelolaan dalam melakukan dakwah. Sehingga dalam hal ini jika dakwah dilaksanakan dengan prinsip manajemen, maka citra profesional akan terwujud. Oleh karena itu, dakwah bukan saja hanya sebagai akitvitas ibadah, tapi juga dimakanai sebagai profesi. Dakwah dapat dianggap efektif jika tujuannya tercapai. Selain itu dalam mencapainya juga membutuhkan pengorbanan yang wajar. Dalam pengertian ini manajemen dakwah dapat diartikan sebagai pengaturan dalam berdakwah sejak perencanaan sampai pada akhir (Yahya, 2019).

Merujuk konsep tersebut, Masjid Darusa'adah telah menerapkan manajemen dalam berdakwah. Salah satunya dapat dilihat ketika beberapa materi dakwah saat Bulan Ramadan selalu berbeda dan dapat dengan mudah diterima. Aktivtias dakwah tersebut juga tidak sebatas dalam makna ibadah, namun juga dapat diartikan sebagai profesi bagi subjeknya.

\section{Masjid Sebagai Ruang Pemberdayaan (Pendidikan) Agama}

Masjid merupakan unsur yang penting bagi umat Islam. Selain sebagai pusat ibadah, masjid juga di gunakan untuk keperuan lain misalnya untuk kegiatan pendidikan. Penggunaan masjid seperti ini juga terdapat sejak zaman Nabi Muhammad saw. Pada masa awal perkembangan Islam, masjid tidak hanya menjadi tempat ibadah namun juga pusat pemeintahan, kegatan pendidikan, kegiata sosial dan ekonomi (Ardyanto, 2013).

Masjid Darusa'adah, sebagaimana masjid pada zaman Rasulullah juga dipakai tidak hanya untuk ibadah namun juga untuk kepentingan lain termasuk kepentigan pendidikan. Kegiatan pendidikan yang dilaksnaakn di masjid Daarussaadah adalah Madrasah Diniyah Takmiliyah Awaliyah (MDTA) dan Pendidikan Anak Usia Dini (PAUD).

MDTA dan PAUD berada di bawah satu kepengurusan. Pengurus ini memiliki tanggung jawab mengatur proses pembelajaran baik dalam mengolah kurikulum, menentukan kalender pendidikan dan mengelola keuangan. Hal ini termasuk di dalamnya mengelola dan 
menentukan sistem pembelajaran MDTA dan PAUD.

Struktur kepengurusan MDTA dan PAUD Daarussaadah adalah sebagai berikut:

Ketua

Sekretaris

Bendahara

Nung Qomariyah

Tata Usaha

Keamanan
: Yayah Zuariyah, S.Pd. I

: Isma Khasanah

: Yeni Yuliani S.S

: Fitri Fauziyah, S. Kom

: Jaelani Abdillah

Menurut ketua MDTA dan PAUD, masjid adalah tempat umum dan rumah Allah sehingga siapapun boleh menggunakannya. Selain itu, memilih masjid sebagai tempat pendidikan juga di dasarkan kepada dalil dari al -Qur'an. Menurut al Qur'an Surat Al-Taubah ayat 18 , orang-orang yang beriman adalah orang yang percaya dengan ahri akhir dan memkamurkan masjid sehingga MDTA dan PAUD sengaja dibangun di aera masjid.

MDTA dan PAUD adalah satu jenis pendidikan yang memiliki warna yang berbeda. PAUD dan MDTA sama-sama memiliki peran sebagai lembaga pendidikan. Perebdaanya adalah MDTA meupakan lembaga pendidikan berbasis Islam sedangkan PAUD adalah lembaga pendidikan yang bersifat umum sehingga PAUD dan MDTA saling beriringan dan melengkapi.

\section{Madrasah Dinniyah Takmiliyah Awaliyah (MDTA)}

Madrsah Diniyah Takmiliyah Awaliyah (MDTA) adalah sekolah agama. MDTA disebut juga Madin (Madrasah Diniyah). Pada hari-hari biasa (selain Bulan Ramadhan) MDTA dilaksanakan setelah Shalat Ashar sampai menjelang magrib. MDTA dilaksanakan setiap hari selain hari rabu, karena pada hari rabu masjid digunakan sebagai tempat pengajian dengan jamaah bapak-bapak dan ibu-ibu.

MDTA Darussa'adah memiliki tujuh kelas yaitu kelas 1 sampai kelas 7 yang dibagi berdasarkan umur dan penguasaan ilmu. Proses beajar mengajar tujuh kelas MDTA ini dilaksanakan di Masjid Darussa'adah dengan membagi ruangan yang ada di masjid. Mislanya lantai satu untuk kelas 4, 5, dan 6. Teras untuk kelas 7. Sedangkan lantai dua digunakan untuk kelas 1, 2 dan 3. 
Dalam sejarahnya, MDTA berdiri sejak tahun 1965. Pada saat berdiri, MDTA ini bernama Tarbiyatul Islam Daarussaadah. Berdirinya MDTA kemudian disusul oleh PAUD. Sejak pendiriannya tersebut, MDTA dapat memiliki izin operasi pada tahun 2010.

MDTA Darussa'adah mengajarkan ilmu-ilmu agama seperti Bahasa Arab, Hadits, Qur'an, Aqidah Akhlak (pelajaran budi pekerti Islmai), fiqih (Hukum Islam). Ilmu-ilmu ini diajarkan oleh guru-guru atau ustadz dan ustadzah. Ustadz-ustadz terdiri dari ustadz senior yang telah mengajar lama sperti Bu Yayah dan ustadz baru yang masih muda seperti Kang Jae.

Peserta didik pada MDTA terdiri atas laki-laki dan didominasi oleh perempuan. Peserta didik dengan jumlah laki-laki lebih banyak, berada pada kelas awal seperti kelas 1 sampai kelas 4 . Sedangkan kelas 5 sampai kelas 7 memiliki jumlah laki-laki yang sangat sedikit. Menurut salah satu ustadzah, hal ini dikarenakan peserta didik lebih suka beger ${ }^{1}$ dan bersenang-senang dari pada mengikuti pendidikan di masjid.

MDTA Daarussaadah memiliki beberapa program kerja, diantaranya adalah mabit atau pesantren kilat pada Bulan Ramadhan. Mabit ini dilaksanakan dalam waktu dua hari satu malam dan diikuti oleh seluruh santri atau peserat didik dari keas 1 sampai 7. Namun, khusus kelas 6 dan kelas 7 lebih banyak dilibatkan untuk membantu panitia.

Kegiatan-kegiatan yang ada selama pesantren kilat antara lain permainan edukatif, mencari jejak, mengajii, buka dan sahur bersama, olah raga bersama dan shalat berjamaah. Pesantren kilat biasanya diadakan selama dua hari satu malam.

\section{Pendidikan Anak Usia Dini (PAUD)}

PAUD Darussa'adah berdiri pada 11 Januari 2011 dan mendapat ijin operasi pada tahun 2013. Pelaksanaan PAUD dalam menggunakan masjid memiliki sedikit perbedaan dengan MDTA. MDTA menggunakan masjid sebagai tempat kegiatan secara penuh, sedangkan kelas PAUD berada di lantai dua masjid, tepatnya di sebelah ruang yang biasa digunakan untuk sholat.

${ }^{1}$ Bermain (dalam Bahasa Sunda) 
PAUD Darussa'adah menggunakan kurikulum yang diambil dari Peraturan Menteri Pendidikan nomor 58 tahun 2009 tentang Pendidikan Anak Usia Dini (PAUD) yang dimodifikasi dengan kurikulum lokal. Salah satu modifikasi kurikulum terdapat pada materi hafalan doa-doa dan surat pendek untuk anak.

Kegiatan belajar mengajar di PAUD Darussa'adah dilaksnakan setiap hari senin sampai kamis pukul 08.00 sampai dengan pukul 11.00 WIB. Namun, ketika Bulan Ramadhan, kegiatan PAUD diliburkan dan kembali aktif setelah Hari Raya Idul Fitri.

Aktivitas pendidikan di PAUD tidak selalu dilaksnakana di lingkungan kelas atau masjid. Peserta didik PAUD juga mengikuti kegiatan outond dan mengikuti berbagai lomba di luar kelas. Beberapa lomba yang telah diikuti oleh peserta didik PAUD Darussa'adah dan berhasil mendapat juara adalah lomba kreasi tari dan lomba senam ceria. Lomba tersebut berhasil mendapat juara ke 3. Acara lain yang diikuti adalah manasiq haji atau simulasi haji dan pencak silat anakanak.

Saat penelitian ini dilakukan, PAUD Darussa'adah memiliki 29 siswa yang dibagi ke dalam dua kelas yaitu kelas A dan kelas B. Wilayah masjid yang dipakai untuk kegiatan PAUD adalah lantai dua dan ruang aula samping masjd di lantai dua yang sengaja di bangun untuk memenuhi kebutuhan PAUD.

Mengamati bentuk pendidikan agama yang diselenggarakan oleh Masjid Darusa'adah tersebut, dapat dilihat sebagai upaya mengembalikan masjid dalam fungsi pendidikan. Fungsi masjid sangat luas, yaitu sebagai tempat mengekspresikan iman kepada Allah SWT dengan berbagai ritual ibadah. Merujuk pada perkembangan masjid pada zaman Rasulullah, masjid juga menjadi lembaga pendidikan utama. Rasulullah melakukan itu di Masjid Nabawi (Darodjat \& Wahyudiana, 2014). Dengan hal tersebut Masjid Darusa'adah telah berupaya untuk mengembalikan peran masjid seperti zaman Rasulullah.

Kegiatan pendidikan tersebut juga dapat dilihat sebagai bentuk pemberdayaan dengan subjek utamanya adalah masjid. Dalam hal ini, perspektif dakwah pemberdayaan masyarakat menjadi relevan. Konsepnya diartikan sebagai dakwah yang bersifat tindakan nyata, 
dilakukan secara profesional, dapat berupa pendampingan dan materinya berupa pemberdayaan masyarakat (Nurjamilah, 2017). Bentuk dari pemberdayaan di Masjid Darusa'adah dengan merujuk pada konsep tersebut dilakukan dengan pendidikan agama.

\section{Masjid Dalam Memperkuat Solidaritas Sosial Keagamaan}

Forum sosial keagamaan yang dilaksanakan oleh Masjid Darussa'adah adalah majelis taklim. Masjid memiliki banyak fungsi baik secara sosial maupun agama. Secara agama, masjid berfungsi sebagai tempat manusia beribadah kepada Tuhannya. Sedangkan secara sosial, masjid dapat berfungsi sebagai tempat membina keutuhan ikatan jamaah dan rasa gotong royong di dalam mewujudkan kesejahteraan bersama. Selain itu, masjid dengan majelis taklimnya merupakan ruang untuk mengingatkan kecerdasan dan ilmu pengetahuan muslim (Ayub, 1996). Sesuai dengan fungsi tersebut, Masjid Darussa'adah mengembangkan kelompok pengajian yang disebut Majelis Taklim Darussa'adah.

Kegiatan majelis Taklim yang dilaksanakan di masjid adalah pengajian rutin. Pengajian ini diikuti oleh bapak-bapak dan ibu-ibu penduduk sekitar masjid. Jadwal pengajian tersebut adalah:

1. Senin - jumat pagi (kecuali rabu): pengajian al-Qur'an ibuibu

2. Rabu setelah ashar: pengajian ceramah untuk bapakbapak dan ibu-ibu

3. Rabu setelah maghrib: pengajian bakap-bapak

4. Sabtu setelah subuh: fiqih untuk bapak-bapak

5. Minggu: pengajian bapak-bapak

Sebagaimana kegiatan lainnya di Masjid Darussa'adah yang dipengaruhi oleh adanya Bulan Ramadan, pengajian-pengajian tersebut juga mengalami perubahan karena menyesuaikan dengan berbagai hal. Misalnya pengajian bapak-bapak yang biasanya dilaksanakan setelah magrib diganti dengan diadakannya ceramah setelah isya sebelum tarawih. Sedangkan pengajian rabu sore diganti menjadi pengajian Al Qur'an setelah sholat tarawih.

Sekilas, kegiatan majelis taklim adalah kegiatan agama dengan materi keagamaan Islam. Pada faktanya, di satu sisi hal ini adalah yang 
terlihat di permukaan. Namun di sisi lain, dalam majelis taklim masyarakat dipertemukan dan dapat membangun relasi sosial. Majelis taklim menjadi ruang dalam menciptakan solidaritas dan integrasi sosial. Masyarakat (bapak-bapak dan ibu-ibu) selain dapat mendalami ilmu agama, juga dapat melakukan interaksi sosial dalam majelis taklim.

Sejak lama, Durkheim telah menjelaskan bahwa solidaritas sosial diartikan sebagai keadaan relasi antar individu dan kelompok yang didasarkan pada perasaan moral dan kepercayaan yang dianut bersama dengan diperkuat oleh pengalaman emosional bersama (Zulaicha, 2000). Durkheim juga menekankan bahwa di balik lapisan teologis dari suatu agama, terdapat lapisan sosiologis yang dapat diungkap (Hefni, 2019). Dengan konsep dari Durkheim tersebut, Masjid Darusa'adah dengan kegiatan majelis taklimnya dapat menjadi dasar terciptanya solidaritas sosial. Masyarakat (jamaah majelis taklim) telah memiliki kepercayaan dan pengalaman emosional bersama. Selain itu, di balik majelis taklim sebagai kegiatan yang berlandaskan teologis, juga terdapat lapisan sosiologis yaitu solidaritas dan integritas sosial.

\section{Pemberdayaan Berbasis Religi Masjid Darusa'adah}

Dalam konsep dasarnya, pemberdayaan dapat diartikan sebagai proses melepaskan situasi yang menjadi masyarakat tidak mampu, tidak berdaya, tersisih dan terpinggitkan. Sehingga pemberdayaan dapat didefinisikan sebagai cara dalam mengubah yang tidak berdaya menjadi berdaya. Dalam hal ini rakyat, masyarakat, ornagisasi, kelompok dan komunitas diarahkan agar dapat berkuasa atas kehidupannya (Ridwanullah \& Herdiana, 2018). Dengan menggunakan konsep ini, pemberdayaan diharapkan dapat mengeluarkan masyarakat dari kondisi yang serba tidak mampu.

Pemberdayaan juga dimaknai sebagai proses pengambilan keputusan oleh masyarakat yang secara konsekuen melaksanakan keputusannya. Masyarakat yang telah mencapai tujuan tersebut harus lebih diberdayakan lewat usaha mereka sendiri dan akumulasi pengetahuan, keterampilan dan sumber lain tanpa bergantung lagi pada pertolongan dari luar (Hikmat, 2013). Dengan melanjutkan 
konsep sebelumnya, pemberdayaan menuntut masyarakat untuk mengambil keputusan dengan dilanjutkan lewat usahanya tanpa bantuan dari eksternal.

Jika merujuk pada kedua konsep tersebut, pemberdayaan telah dilaksanakan oleh Masjid Darus'saadah dengan berbasis pada religi. Perspektif yang digunakan adalah ketika mengambil peran dalam religi, pendidikan dan kultural. Selain dalam hal religi yang sudah sangat jelas sebagai peran utama masjid, dalam hal pendidikan, Masjid Darussa'adah telah dapat memberikan sumbangan untuk pembelajaran anak-anak (MDTA dan PAUD). Sedangkan dalam hal sosio kultural bahwa perannya dalam kegiatan majelis taklim dapat menciptakan integrasi sosial.

Menurut Jim Ife salah seorang ahli dalam community development, dalam melaksanakan kegiatan pengembangan atau pemberdayaan masyarakat dibutuhkan solidaritas yang kuat. Hal ini diartikan sebagai sebuah bentuk kerjama antara pekerja sosial dengan masyarakat. Seorang pekerja sosial tidak disarankan untuk bekerja sendiri atau menjadi aktor bebas. Namun, dia harus mau bergabung dalam perjuangan masyarakat (Ife \& Tesoriero, 2008). Begitu juga yang telah dilakukan Masjid Darussa'adah di mana seorang pendidik dapat menjadi satu dengan peserta didik. Bahkan, dalam majelis taklim antara individu yang menjadi jamaah dapat bersatu dalam wadah kajian keislaman.

Selain konsep solidaritas, menurut Paulo Freire dibutuhkan sebuah konsep bebas dalam pemberdayaan berbasis pendidikan. Menurutnya, perubahan dalam pemberdayaan memerlukan pendekatan humanisme, dalam rangka membebaskan masyarakat dari tekanan yang ada. Baginya aksi dari tekanan adalah sesuatu yang palsu bagi oang yang tertekan dan bahkan dia mekakukan tekanan ulang terhadap orang yang berada di bawah dominasinya (Hikmat, 2013). Sehingga, untuk mencegah terjadinya hal tersebut Masjid Darusa'adah menyelenggarakan pendidikan dengan pendekatan religi. Melalui pendekatan agama, masyarakat menganggap lebih mudah dan nyaman untuk menerimanya.

Terakhir, Masjid Darussa'adah sebagai tempat ibadah sekaligus lembaga Islam juga melaksanakan "dakwah bi al-hal". Konsepnya 
adalah bahwa lembaga Islam ini memiliki kewajiban untuk berdakwah yang salah satunya dapat dilaksanakan dengan dakwah bi al-hal. Aktivitas dan kegiatan tersebut bertujuan untuk memberdayakan dan meningkatkan pemahaman agama masyarakat sekitar. Sehingga antara pemberdayaan dan dakwah bi al-hal saling memiliki keterkaitan (Ali \& Hasan, 2019). Sampai pada pengertian ini, segala kegiatan di Masjid Darus'saadah Kota Bandung merupakan program pemberdayaan berbasis religi dengan tujuan meningkatkan pemahaman agama, pendidikan, solidaritas dan integrasi sosial.

\section{Kesimpulan}

Masjid sebagai tempat ibadah bagi umat Muslim telah berjalan sekian lama. Namun secara histori, masjid juga memilik peran dan fungsi lain seperti pendidikan, sosial, kultural dan politik. Hal itu lah yang dilakukan di Masjid Darussa'adah Kota Bandung. Masjid Darusa'adah selain menjadi tempat ibadah juga memiliki peran dan fungsi lain. Pertama, seperti masjid pada umumnya, Masjid Darusa'adah juga berfungsis sebagai tempat ibadah umat Islam. Kedua, peran dan fungsi yang dilaksanakan adalah berkaitan dengan pendidikan. Lebih tepatnya pendidikan keagamaan Islam dengan peserta didik anak-anak yaitu melalui MDTA dan PAUD. Ketiga, Masjid Darussa'adah juga berperan dalam memperkuat solidaritas sosial dan menciptakan integrasi sosial melalui majelis taklim. Selain untuk mengembalikan peran masjid seperti zaman Rasulullah, semua program ini juga bertujuan untuk meningkatkan pemahaman agama, dakwah bi al-hal, kebersamaan, solidartias dan integrasi sosial.

\section{Daftar Pustaka}

Ali, M., \& Hasan, S. (2019). Da'wah bi al-Hal in Empowering CampusAssisted Community through Waste Bank Management. Ilmu Dakwah: Academic Journal for Homiletic Studies, 13(2), 201-219. https://doi.org/10.15575/idajhs.v13i2.6441

Amir, F. R., \& Nasution, S. A. (2018). Pemberdayaan Masyarakat Melalui Kegiatan Pendidikan, Agama, Sosial, Ekonomi, Dan Kesehatan. Qardhul Hasan: Media Pengabdian Kepada Masyarakat, 3(1), 61. https://doi.org/10.30997/qh.v3i1.1001

Ardyanto, R. (2013). Pemberdayaan Masjid Perspektif Politik Islam Studi 
Kasus Masjid Syuhada' Yogyakarta 2008-2013. UIN Sunan Kalijaga Yogyakarta.

Ayub, M. E. (1996). Manajemen Masjid. Jakarta: Gema Insani Press.

Ayubi, H. Al. (2008). Fungsi dan Kegiatan Masjid Dian Al Mahri sebagai Objek Wisata Rohani. UIN Syarif Hidayatullah Jakarta.

BPS. (2020). Penduduk Kelurahan Dago Kecamatan Coblong menurut Kelompok Umur. Bandung.

Darodjat, \& Wahyudiana. (2014). Memfungsikan Masjid Sebagai Pusat Pendidikan Untuk Membentuk Peradaban Islam. Jurnal Islamadina, XIII(2), 1-13.

Endang, H., Gufron, R., Zaenudin, S., \& Rahman, A. S. (2012). Al Quran Cordoba Special For Muslimah. Bandung: Cordoba Internasional Indonesia.

Furseth, I., \& Repstad, P. (2006). An Introduction to the Sociology of Religion: Classical and Contemporary. England: Ashgate Publising Limited.

Hefni, W. (2019). Perempuan, Jilbab, dan Solidaritas Kemanusiaan: Studi Gerakan Perempuan Berhijab Pasca Tragedi New Zealand. Sawwa: $\begin{array}{llll}\text { Jurnal Studi Gender, } & \end{array}$ https://doi.org/10.21580/sa.v14i1.3511

Hikmat, H. (2013). Strategi Pemberdayaan Masyarakat (6th ed.; U. S. Artyasa, Ed.). Bandung: Humaniora.

Ife, J., \& Tesoriero, F. (2008). COMMUNITY DEVELOPMENT: Alternatif Pengembangan Masyarakat di Era Globalisasi. Yogyakarta: Pustaka Pelajar.

Johnston, E. (2013, December 22). Kyoto Aims To Be Muslim-Friendly City. Japantimes, p. $1 . \quad$ Retrieved from https://www.japantimes.co.jp/news/2013/12/22/national/kyotoaims-to-be-muslim-friendly-city/

Karim, H. A. (2020). Revitalisasi Manajemen Pengelolaan Peran Dan Fungsi Masjid Sebagai Lembaga Keislaman. Isema: Islamic Education Management, 5(2), 139-150.

Katadata.co.id. (2018). Indonesia, Negara dengan Penduduk Muslim Terbesar Dunia. In Datapublish. Indonesia.

Kemenag. (2020). Sistem Informasi Masjid. Retrieved February 15, 2021, from https://simas.kemenag.go.id/

Kharis, A. (2019). Kampung Wisata Berbasis Masjid di Kampung Sayidan Prawirodirjan Yogyakarta. Islamic Management and Empowerment Journal, 1(1), 101. https://doi.org/10.18326/imej.v1i1.101-128

Nurjamilah, C. (2017). Pemberdayaan Masyarakat Berbasis Masjid dalam Perspektif Dakwah Nabi saw. Journal of Islamic Studies and 
Humanities, 1(1), 93. https://doi.org/10.21580/jish.11.1375

Putra, A., \& Rumondor, P. (2019). Eksistensi Masjid Di Era Rasulullah. Tasamuh, 17(1),

245-264. https://doi.org/10.20414/tasamuh.v17i1.1218

Ridwanullah, A. I., \& Herdiana, D. (2018). Optimalisasi Pemberdayaan Masyarakat Berbasis Masjid. Ilmu Dakwah: Academic Journal for Homiletic Studies, https://doi.org/10.15575/idajhs.v12i1.2396

Yahya. (2019). Lembaga Dakwah dan Wasatiyah: Sebuah Tela'ah Perspektif Manajemen Dakwah di Kota Salatiga. Islamic Management $\begin{array}{llll}\text { and Empowerment Journal, } & 79 .\end{array}$ https://doi.org/10.18326/imej.v1i1.79-100

Zulaicha, S. (2000). Studi Teoritis Tentang Integrasi dan Solidaritas Sosial Menurut Durkheim dan Tindakan Sosial Menurut Weber. IAIN Sunan Ampel Surabaya. 